Ethiopian Journal of Environmental Studies \& Management 7(4): 452 - 459, 2014.

ISSN:1998-0507

doi: http://dx.doi.org/10.4314/ejesm.v7i4.12

Submitted: May 24, 2014

Accepted: July 26, 2014

\title{
EFFECTS OF INFRASTRUCTURAL DEVELOPMENT ON RESIDENTIAL PROPERTY VALUES IN MINNA
}

\author{
AJAYI, M.T.A., ${ }^{1}$ JIMOH, 0.J. ${ }^{1}$ AND ${ }^{*}$ JIMOH, R.A. ${ }^{2}$ \\ ${ }^{1}$ Department of Estate Management and Valuation, Federal University of Technology, Minna \\ Nigeria \\ ${ }^{2}$ Department of Building, Federal University of Technology, Minna-Nigeria
}

\begin{abstract}
The provision of adequate infrastructure is a tool for driving economic development within a given locality. The availability of relevant infrastructure to sustain human development which can be social or economic in nature is expected to enhance the income to be generated from the use of such human development. However, rental value which is an income to be generated from property development which is a form of human development is expected to be influenced by the provision of appropriate infrastructure that will enhance the sustainability of residential property in this instance. In order to examine the effect of Infrastructure on residential property value the research adopted a mixed of quantitative and qualitative method of research. The study adopted a purposive selection of 8 practising estate surveyors within the study area and randomly distributed 400 questionnaires to the residents of Tunga and Bosso. The result indicates that with a minimum of $84 \%$, tarred road is the predominant infrastructure in the selected areas while the regression analysis with coefficient of determination $\left(R^{2}\right)$ of $49.3 \%$ indicates that time taken on the road is not a factor for consideration in selection of residential property. In essence the type of road provided in the study area does not have any effect on residential property value.
\end{abstract}

Keywords: Infrastructure, Residential Property, Rental Value, Road, Time Taken

\section{Introduction}

Infrastructure is an umbrella term for many activities referred to as "social overhead capital", which include public utilities such as power, telecommunication, water supply, sanitation and sewerage; and public works such as roads, dams, and drainage (World Bank, 1994). Hirschman (1958) describes infrastructure as those services without which primary, secondary and tertiary economic activities cannot function. In its widest sense it includes all public services, ranging from law and order, through education and public health to transportation, communication, power and water supply as well as agricultural facilities such as irrigation and drainage systems. The adequacy of infrastructure helps to determine the level of success that a country achieves in terms of coping with population growth, reducing poverty, or improving environmental conditions (World Bank, 1994). In a report on a related development, Khan and Haupt (2006) state that one of the benchmarks used in determining the wellbeing of the populace is to have the minimal infrastructural services. Evidence suggests that inadequate infrastructure is an impediment to the rate of growth in Africa, which has resulted in some African countries trailing behind other developing countries (Foster and Briceno-Garmendia, 2010).

Developing countries, according to the World Bank (1994), invested \$200 billion per year in new infrastructure. This has resulted in a dramatic increase in infrastructure

*Corresponding Author: Jimoh, R.A.

Email: rosney@futminna.edu.ng 
services leading to higher productivity and improved standard of living. But in spite of this positive information, close to 3 billion people, or about $40 \%$ of the world's population will be in need of adequate housing and basic infrastructure services by 2030 (UN-Habitat, 2007). According to the United Nations (2010) 884 million people lack access to potable water and 2.6 billion people lack access to basic sanitation services. To bridge this infrastructural deficiency gap in sub-Saharan Africa, Foster and Briceno-Garmendia (2010) indicated that $\$ 93$ billion is needed yearly. Infrastructure and the provision of housing are, according to Otegbulu and Adewunmi (2009), closely related; to have housing that is sustainable, there is a need for the provision of infrastructure.

For developing countries, investments in infrastructure have benefits as well as costs associated with the benefits. Adequate transportation, communication, and power generation can boost productivity and growth. Conversely, where income and productivity are depressed by inadequate infrastructure, the financial resources needed may be huge and the challenges of obtaining finance may be serious and difficult to overcome. Lack of infrastructure limits investment and the lack of investment limits infrastructure, this may not be unconnected with the level of investments seen in developing countries (Eichengreen, 1995).

For many countries, infrastructural variables are positively and significantly correlated with growth and development. Providing appropriate infrastructure in developing countries can play a vital role in poverty reduction. The development of social infrastructure is important in contemporary societies where education and healthcare are strategic factors for economic growth, social progress and the competitiveness of the country in global markets (Chulanova, 2007).
Beesley (1974) has found that efficient provision of infrastructure is usually characterized by heavy capital outlay, indivisibility of benefits and high externalities. Government is usually called upon to provide such facilities, especially in the developing economies. In countries where the development of this infrastructure has followed a rational, coordinated and harmonized path, growth has received a big boost. This is because infrastructure provision and development serve as input into private sector production, thus facilitating output growth and productivity.

\section{Rental Value}

There is a close relationship between rent and value. Rent can be defined as the sum payable by a tenant to his landlord for the use of his property, usually annually (Olusegun, 2003). Olusegun (2003) stated that the rental value of a property is the amount that a prospective tenant can afford to pay for its occupation. In the case of residential properties, occupation is a need and does not usually serve a profit making function; the rental value of such a property will be determined by the level of demand and supply. Millington (1997) defines rental value as the maximum rent which a property can reasonably be expected to let in an open market. He went further to state that the rental value of a property can be fixed at a particular time assuming the following conditions exist, a willing and able buyer; the property will be freely exposed to the market; value will remain static throughout the period of negotiation and a reasonable time period within which to negotiate the rent taking into consideration nature of the property and state of the market.

\section{Relevance of Infrastructural Development to Property}

Ratcliffle (1995) in his classical rent theory conceptualizes that general improvement in access routes (roads) has 
positive effect on land and property values. The provisions of infrastructure in any social - economic unit whether a nation, a region or community could either have a positive or negative effect on property. For example, the provision of incinerators on residential districts will have a negative effect on the value of properties within that area while the provision of infrastructure like good road network, water, electricity, good drainage system etc. will have positive effects on the value of properties.

Boyce and Allen (1974) study the impact of accessibility and amenities on the value of properties. The selected study areas then applied six criteria encompassing accessibility, amenities and property characteristics, and used regression analysis to investigate twenty four thousand and eighty two property transactions. They identified a positive impact of value on property as a result of the infrastructure.

According to Kockelman (1997), household's location decision depends, to a large degree, on access to opportunity sites. With regards to budget, time, and other constraints, it is a common assumption that households maximize their utility by locating in as desirable a home as possible as near to necessary and desired activities such as work as possible. This utility maximisation is dependent on environmental attributes than those that can be observed and quantified.
Carey (2001) asserts that many researchers agree that the net effects associated with road transportation development are not directly comparable from one region to another. To this end, generalising among various locales may not be appropriate. This may be the reason why Siethoff et al., (2002) state that the effects of transportation improvements on property value have been comprehensively studied but are still not well understood. It is on the basis of this that the paper sought to assess the effect of infrastructural development (road transportation) on residential property value in Tunga and Bosso in Minna-Nigeria.

\section{Study Area}

Minna, the state capital of Niger State and a famous railway town, lies approximately on latitude $9^{0} 71^{1}$ North and Longitude $6^{0} 33^{1}$ East. However, the town has transformed from a small traditional settlement to an urban centre with modern facilities and amenities. The State is largely agrarian (Ministry of Lands and Housing Minna, 2012). According to Adedayo and Sulyman (2013), the State at the inception in 1976 had only eight Local Government Areas (LGAs), this has increased to twenty-five due to boundary adjusted and creation of additional Local Government Areas. Figure 1 is a map of Niger State showing the location of Minna, its capital, on eastern part of the state. 


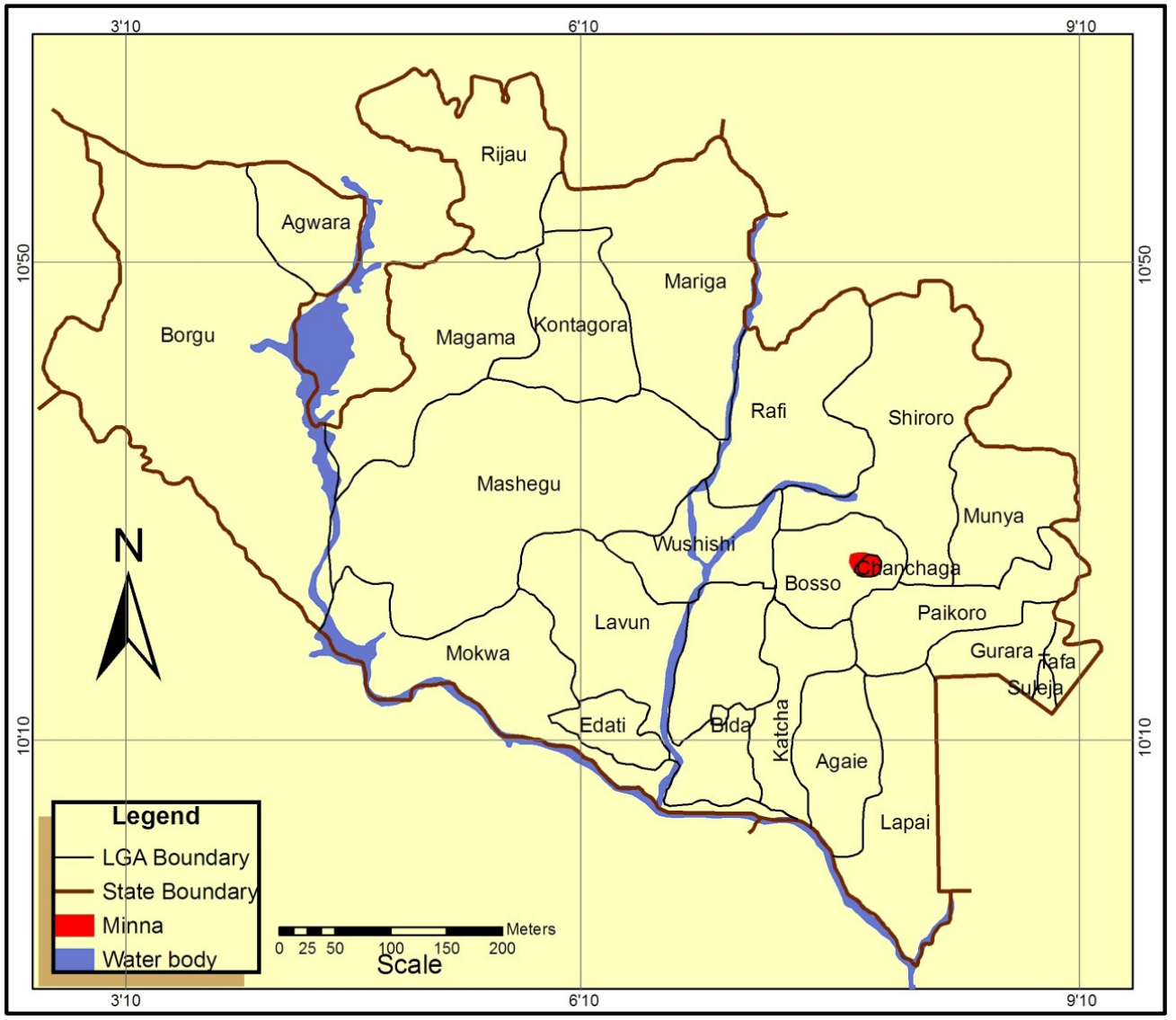

Figure 1: Map of Niger State Showing Minna

Source: Ministry of Lands and Housing, Minna (2012).

\section{Research Methodology}

The adopted methodology followed the mixed methods approach. Johnson et al. (2007) describe a mixed methods approach as a class of research where the researcher mixes or combines quantitative and qualitative research techniques, methods, approaches, concepts or language into a single study for the purpose of breadth and depth of understanding. As a result of the insufficiency of the first set of data collected, the embedded design method, as described by Creswell and Clark (2011), was used. The design is such that one set of data is used to provide support for the other set and as such the supportive data is said to be embedded in the main data. The second set of data (the survey) provided the support for the historical data sourced from the offices of Estate Agents around the areas studied.

In determining the number of Estate Agents to include in the study, purposive sampling was used. Historical data from 1998-2009 was extracted from the records of the 8 Estate Agents sampled. Simple regression analysis was done using the Statistical Package for Social Scientists (SPSS) for data analysis. In addition, 400 questionnaires were randomly selfadministered to residents of the areas. Finally, inferences were drawn that formed the basis for the conclusion.

\section{Results and Discussion}

Table 1 shows that there is road accessibility which is predominant in the study areas constituting $85 \%$ and $82 \%$ in 
Tunga and Bosso respectively. The results of this study supported earlier study of Boyce and Allen (1974) on impact of accessibility and amenities on property values.

From table 2, it is seen that the predominant type of road that exists in the study areas are tarred road constituting 90\% and $84 \%$ in Tunga and Bosso respectively.
Also, since the rental values of residential properties in Tunga is higher than the rental values of residential properties in Bosso, it means the difference in rental values of the residential properties in the two neighbourhoods (Tunga and Bosso) could be as a result of the tarred roads since more roads were tarred in Tunga than Bosso.

Table 1: Road accessibility in the study areas

\begin{tabular}{lllll}
\hline Road accessibility & Tunga (f) & \% occurrence & Bosso (f) & \% occurrence \\
\hline Yes & 163 & 85 & 152 & 82 \\
No & 29 & 15 & 34 & 18 \\
Total & 192 & 100 & 186 & 100 \\
\hline
\end{tabular}

Table 2: Type of road in the study areas from the nearest junction

\begin{tabular}{lllll}
\hline Type of road & Tunga (f) & \%occurrence & Bosso (f) & \%occurrence \\
\hline Tarred road & 173 & 90 & 156 & 84 \\
Dirt road & 19 & 10 & 30 & 16 \\
Total & 192 & 100 & 186 & 100 \\
\hline
\end{tabular}

Table 3: Consensus opinion of respondents on traffic situation in Tunga

\begin{tabular}{llll}
\hline Opinion & Sum & $\begin{array}{l}\text { Mean } \\
\text { (sum/192) }\end{array}$ & $\begin{array}{l}\text { Interpretation } \\
\text { (consensus opinion) }\end{array}$ \\
\hline 7.am-10a.m & 501 & 2.61 & Sometimes heavy \\
1.pm-3.pm & 523 & 2.72 & Sometimes heavy \\
5.pm-6.30pm & 540 & 2.81 & Sometimes heavy \\
\hline
\end{tabular}

The following is then devised to mark the cut-off points for interpretation (Morenikeji, 2006).

1 - 1.5------------------ No traffic

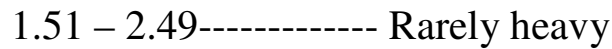

2.50 - 3.49------------ Sometimes heavy

$3.50-4.49------------~ H e a v y$

4.50 - 5.00------------- Very heavy

From Table 3 above, it can be seen that the respondent's consensus opinion is "sometimes heavy". Hence, it can be concluded that within the hours of 7.am - 10.am, 1.pm - 3.pm and 5.pm $-6.30 \mathrm{pm}$, the traffic is "sometimes heavy" in Tunga.

Table 4: Consensus opinion of respondents on traffic situation in Bosso

\begin{tabular}{llll}
\hline Opinion & Sum & $\begin{array}{l}\text { Mean } \\
\text { (sum/186) }\end{array}$ & $\begin{array}{l}\text { Interpretation } \\
\text { (consensus opinion) }\end{array}$ \\
\hline 7.am-10a.m & 490 & 2.63 & Sometimes heavy \\
1.pm-3.pm & 481 & 2.59 & Sometimes heavy \\
5.pm-6.30pm & 526 & 2.83 & Sometimes heavy \\
\hline
\end{tabular}


From the above table, it can be seen that the respondent's consensus opinion is "sometimes heavy". Hence, it can be concluded that within the hours of 7.am - 10.am, 1.pm - 3.pm and 5.pm $-6.30 \mathrm{pm}$, the traffic is "sometimes heavy" in Bosso.

In conclusion, the traffic situation in Tunga and Bosso has no effects on the rental values of residential properties as a result of the similarity in their traffic situations (sometimes heavy).

Table 5: Multiple regression analysis of the annual growth rate of the residential units (single room, one bedroom, two bedroom and three bedroom) against time taken to travel on the road in Tunga

ANOVA

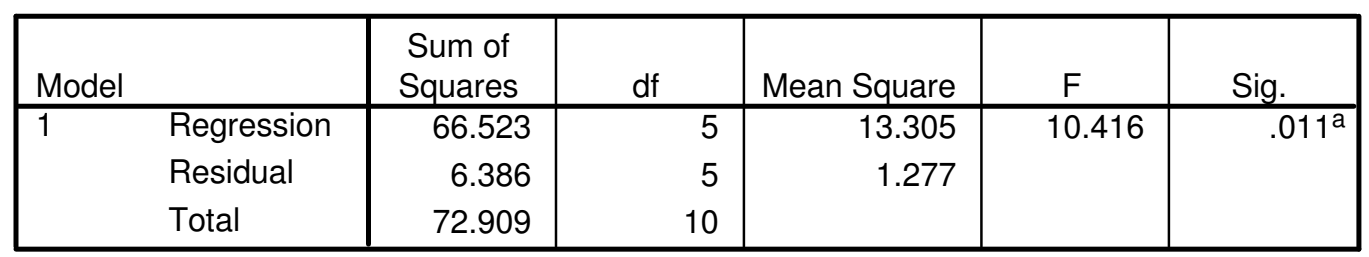

a. Predictors: (Constant), anngrththre, anngrthone, anngrthtwo, trfcvol, anngrthsng

b. Dependent Variable: tymtkn

Coefficients $^{\mathrm{a}}$

\begin{tabular}{|c|c|c|c|c|c|c|}
\hline \multirow{2}{*}{\multicolumn{2}{|c|}{ Model }} & \multicolumn{2}{|c|}{$\begin{array}{c}\text { Unstandardized } \\
\text { Coefficients }\end{array}$} & \multirow{2}{*}{$\begin{array}{c}\begin{array}{c}\text { Standardized } \\
\text { Coefficients }\end{array} \\
\text { Beta }\end{array}$} & \multirow[b]{2}{*}{$t$} & \multirow[b]{2}{*}{ Sig. } \\
\hline & & B & Std. Error & & & \\
\hline & (Constant) & -1.809 & 1.050 & & -1.723 & .145 \\
\hline & trfcvol & .036 & .005 & .980 & 6.806 & .001 \\
\hline & anngrthsng & .013 & .036 & .070 & .374 & .724 \\
\hline & anngrthone & -.054 & .070 & -.141 & -.777 & .473 \\
\hline & anngrthtwo & .019 & .040 & .067 & .476 & .654 \\
\hline & anngrththre & -.005 & .052 & -.014 & -.095 & .928 \\
\hline
\end{tabular}

a. Dependent Variable: tymtkn

Based on the above table, it can be deduced that there is no statistical relationship between the annual growth rate for single rooms and time taken on the road in the study area. Hence, the null hypothesis cannot be rejected. The same goes with one bedroom, two bedroom and three bedroom. However, there is a statistical significant difference between the time taken to travel on the road and the traffic volume along the road.

Table 6: Multiple regression analysis of the annual growth rate of the residential units (single room, one bedroom, two bedroom and three bedroom) against time taken to travel on the road in Bosso 
ANOVA

\begin{tabular}{|ll|r|r|r|r|r|}
\hline Model & & Sum of & & & & \\
\hline 1 & Regression & Squares & df & Mean Square & F & Sig. \\
& Residual & 1.417 & 5 & 9.862 & 34.794 & $.001^{\mathrm{a}}$ \\
& Total & 50.727 & 5 & .283 & & \\
\end{tabular}

a. Predictors: (Constant), trfcvol, anngthsngl, anngth2a, anngth3a, anngth1a

b. Dependent Variable: tymtakn

Coefficients $^{\mathrm{a}}$

\begin{tabular}{|c|c|c|c|c|c|c|}
\hline \multirow{2}{*}{\multicolumn{2}{|c|}{ Model }} & \multicolumn{2}{|c|}{$\begin{array}{c}\text { Unstandardized } \\
\text { Coefficients }\end{array}$} & \multirow{2}{*}{$\begin{array}{c}\begin{array}{c}\text { Standardized } \\
\text { Coefficients }\end{array} \\
\text { Beta }\end{array}$} & \multirow[b]{2}{*}{ t } & \multirow[b]{2}{*}{ Sig. } \\
\hline & & B & Std. Error & & & \\
\hline \multirow[t]{6}{*}{1} & (Constant) & 15.087 & .781 & & 19.315 & .000 \\
\hline & anngthsngl & .049 & .043 & .168 & 1.133 & .309 \\
\hline & anngth1a & -.116 & .087 & -.390 & -1.330 & .241 \\
\hline & anngth2a & . 077 & .086 & 179 & .890 & .414 \\
\hline & anngth3a & .128 & 106 & 342 & 1.208 & 281 \\
\hline & trfcvol & -.071 & .007 & -1.052 & -9.546 & .000 \\
\hline
\end{tabular}

a. Dependent Variable: tymtakn

Based on the above table, it can be deduced that there is no statistical relationship between the annual growth rate for single rooms and time taken on the road in the study area. Hence, the null hypothesis cannot be rejected. The same goes with one bedroom, two bedroom and three bedroom. However, there is a statistical significant difference between the time taken to travel on the road and the traffic volume along the road.

\section{Conclusion}

The paper assessed the effects of road infrastructure on the residential property values in Minna. Based on the analyses carried out, it could be concluded that road network within the study areas was a consideration in the determining where occupants reside due to the nature of the roads in Tunga and Bosso. Rental value in Tunga was higher than Bosso which may be as a result of the better state of roads in Tunga. However, there was a statistical relationship between the time taken to traverse and the traffic volume at various time of the day in the two areas. Of note is that there were no statistical relationships within the various time taken to get to the major road and the annual growth of the various residential units in the areas studied. This is in line with Kockelman (1997) which stated that household's location decision depends, to a large degree, on access to opportunity sites.

\section{References}

Adedayo, A. and Sulyman, A.O. (2013). Pattern of infrastructure-induced socioeconomic development in rural settlements of Niger State, Nigeria. Ethiopian Journal of Environmental Studies and Management, 6 (Supplement): 802-816

Beesley, M.E. (1974). Urban transportation: Studies in economic policy. The Economic Journal, 84(335): 689-691

Boyce, D.E. and Allen, B. (1974). Impact of rapid transit suburban residential property value and land development. 
Report to the US Department of Transportation.

Carey, J. (2001). Impact of Highways on Property Values: Case Study of the Superstition Freeway Corridor. Arizona Department of Transportation, United States, pp 1-86

Chulanova, Z. (2007). Poverty Reduction in Developing Countries via Infrastructure Development \& Economic Growth: Mutual Impact in Kazakhstan. Asian Development Bank Institute Discussion Paper no. 62.

Creswell, J.W. and Clark, V.L.P. (2011). Designing \& conducting mixed methods research, $2^{\text {nd }}$ edition. California: Sage Publications, Inc.

Eichengreen, B. (1995). Financing Infrastructure in Developing Countries: Lessons from the Railway Age. The World Bank Research Observer, 10(1).

Foster, V. and Briceno-Garmendia, C. (Eds.) (2010). Africa's infrastructure: A time for transformation. Washington: The World Bank.

Hirshman, A. (1958). Strategies for Economic Development. United States: Yale University Press

Johnson, R.B., Onwuegbuzie, A.J, and Turner, L.A. (2007). Toward a definition of mixed methods research. Journal of Mixed Methods Research, 4(4).

Khan, Z. and Haupt, T.C. (2006). Community participation - a necessary element of community development projects. ACTA Structilia, 13(2).

Kockelman, K.M. (1997). The effects of location elements on home purchase prices and rents: Evidence from the San Francisco Bay Area. Transportation Research Record 1606: 40-50, 1-30. Department of Civil Engineering, University of Toronto, Canada

Millington, A. F. (1997). An Introduction to Property Valuation, $4^{\text {th }}$ Edition. London: The Estate Gazette Limited.
Ministry of Lands and Housing Minna (2012). Map of Niger State showing Minna. A brochure published by the Niger State Geographica Information System Center. Niger State.

Morenikeji, W. (2006). Research \& Analytical Methods (For Scientists, Planners and Environmentalist). Jos University Press Ltd. Jos.

Olusegun, K. (2003). Property Valuation, Principles and Practice, Lagos: Olusegun Kuye and Associates.

Otegbulu, A. and Adewunmi, Y. (2009). Evaluating the sustainability of urban housing development in Nigeria through innovative infrastructure management. International Journal of Housing Markets and Analysis, 2(4).

Ratcliffle, J. (1995). The Valuation of Development Properties, Journal of Valuation. Vol. 1.

Siethoff, B., Kockelman, K.M. and Luce, C.B. (2002). Property Values and Highway Expansions: An Investigation of Timing, Size, Location, and Use Effects. Transportation Research Record No. 1812:191-200, Department of Civil Engineering, University of Toronto, Canada, pp 1-22

UN-Habitat (2007). Business for sustainable urbanisation: Challenges and opportunities. Available from: www.UN-Habitat.org/.../2344_alt[1].pdf (Accessed 26 January 2010).

United Nations (2010). We can end poverty by 2015: Millennium Development Goals Fact Sheet. High-level plenary meeting of the General Assembly, 2022 September. Available from: www.un.org/millennium/.../MDG_FS 7 E N.pdf (Accessed 22 March 2011).

World Bank (1994). Infrastructure for Development: World Development Report, Executive Summary, Washington, D.C. 